\title{
Comparison of the efficacy of two sheep pox vaccines derived from Bakırköy strain in cattle against lumpy skin disease
}

\author{
Serdar Uzar ${ }^{1}$, Fahriye Sarac ${ }^{1}$, Veli Gulyaz ${ }^{2}$, Huseyin Yilmaz ${ }^{3}$, Hakan Enul ${ }^{1}$, and Nuri \\ Turan $^{3}$ \\ ${ }^{1}$ Istanbul Pendik Veterinary Control Institute \\ ${ }^{2}$ Republic of Turkey Ministry of Food Agriculture and Livestock \\ ${ }^{3}$ Istanbul University Faculty of Veterinary Medicine
}

August 28, 2020

\begin{abstract}
Lumpy Skin Disease virus (LSDV) is involved in the genus Capripoxvirus(CaPV) of the family Poxviridae. Sheep and goat pox (SGP) vaccine is used heterologously against Lumpy Skin Disease(LSD) in Turkey. In the presented study, it was investigated the propagation of SGP vaccine virus that attenuated in primary lamb kidney cell, in bovine origin MDBK cells and evaluated the immunity of vaccine against LSD in cattle with comparison to the commercial SGP vaccine (Penpox-M) are used in the field. 2 cattle were vaccinated with 10 doses of SGP vaccine produced in MDBK. In efficacy study, 3 cattle were vaccinated with SGP vaccine produced in MDBK, 3 cattle vaccinated with Penpox-M. 2 cattle were not vaccinated as control animal. After vaccination on the day 31, all animals were challenged with virulent Pendik strain and blood samples were taken periodically. Logarithmic differences of the challenge titres between vaccinated and non-vaccinated were calculated. In safety study, clinical sign wasn't observed in animals vaccinated with 10 doses. It was determined that difference between the animals vaccinated with vaccine produced in MDBK cell and unvaccinated was less than log 2.5 and the viremia occurred in vaccinated animals. The titre difference was higher than $\log 2.5$ in animals vaccinated with the Penpox-M, and viremia didn't occur. In conclusion, this study revealed that SGP vaccine virus was propagated in MDBK cells and it is safe to administered in cattle but it didn't provide fully protection, Penpox-M provided protection against LSD.
\end{abstract}

\section{Hosted file}

Comparison and efficacy of two different sheep pox vaccines prepared from the Bakirkoy strain against L available at https://authorea.com/users/354564/articles/478096-comparison-of-the-efficacyof-two-sheep-pox-vaccines-derived-from-bak\%C4\%B1rk\%C3\%B6y-strain-in-cattle-against-

lumpy-skin-disease

\section{Hosted file}

Figure.docx available at https://authorea.com/users/354564/articles/478096-comparison-ofthe-efficacy-of-two-sheep-pox-vaccines-derived-from-bak\%C4\%B1rk\%C3\%B6y-strain-in-cattleagainst-lumpy-skin-disease

\section{Hosted file}

Table.docx available at https://authorea.com/users/354564/articles/478096-comparison-ofthe-efficacy-of-two-sheep-pox-vaccines-derived-from-bak\%C4\%B1rk\%C3\%B6y-strain-in-cattleagainst-lumpy-skin-disease 